\title{
Feedstock Recycling of Plastics Waste for Electricity or Fuel: An Exergy Approach
}

\author{
Marek Stelmachowski \\ Department of Safety Engineering, Faculty of Process and Environmental Engineering, Lodz University of Technology, Lodz, Poland \\ Email address: \\ marek.stelmachowski@p.lodz.pl \\ To cite this article: \\ Marek Stelmachowski. Feedstock Recycling of Plastics Waste for Electricity or Fuel: An Exergy Approach. International Journal of \\ Materials Science and Applications. Vol. 6, No. 5, 2017, pp. 250-259. doi: 10.11648/j.ijmsa.20170605.14
}

Received: July 5, 2017; Accepted: July 25, 2017; Published: September 26, 2017

\begin{abstract}
Waste plastics contribute to many environmental and social problems due to the loss of natural resources, environmental pollution, depletion of landfill space, and the various demands of an environmentally oriented society. The consumption of plastics waste increases annually, particularly in developing countries. Feedstock recycling of scrap polymers by thermal and chemical methods is well known and environmentally acceptable. However, new technologies for waste utilization as well as the methods that would enable an objective and broad assessment of these processes are strongly needed. Selecting the best method for thermal processing of waste polymers can be done based on a thermodynamic analysis of the process. In the paper, the process of thermal degradation of waste plastics (that is carried out in the new type of a tubular reactor with molten metal) is described and evaluated from the therodynamic poin of view. Depending on the final product (a fuel-like mixture or electricity), the calculated exergy efficiency of the proposed method ranged from $79 \%$ to $82 \%$. These results mean that feedstock recycling of this type of waste by thermal degradation is a beneficial process from an energetic and ecological perspective as compared to other processes, particularly incineration.
\end{abstract}

Keywords: Waste Plastics, Exergy, Feedstock Recycling, Fuel from Waste, Electrical Power from Waste

\section{Introduction}

Waste management systems and energy production systems will have to undergo changes due to energy crises and the threat of global climate change. Reduction of the volume of plastic waste at the source, which is the favored method among sustainable development strategies, is very difficult to implement. However, it is believed that reuse, recycling (by different technologies), and incineration (with heat recovery) can lead to good results and thus should be regarded as primary methods in waste management. It is essential, therefore, that environmental strategies in which scrap polymers are considered an energy source be connected with the larger energy systems worldwide. Prior to choosing plastic utilization technology and making investment decisions, it is important to have knowledge of the consequences of these different choices. Thus far, several methods focusing on different technological, economic, and environmental aspects have been developed to estimate the benefits and losses of such decisions. Comparing the energy efficiency of waste utilization processes based on exergy calculations is one of the best methods for the assessment.

Feedstock recycling by thermal and chemical methods can be used to convert scrap polymers into useful products. These methods, which include gasification, liquefaction, liquefaction with hydrogenation, hydrolysis, pyrolysis, and thermocatalytic degradation, are well known and environmentally acceptable. Practically, each of the mentioned methods enables to reduce the impact of waste plastics on the environment as well each of them may be a cheap source of energy and useful raw materials. The processes are generally based on the thermal or catalytic cracking or on the typical pyrolysis. Several commercial technologies, available for thermal degradation of postconsumer plastics allow to obtain a fuel-like liquid mixture of hydrocarbons as a basic product [1, 2]. However, industrial plants using this process are rare or were in operation for only a very short time. The proposed technologies and reactors are still far from perfect, and their profitability is weak. With these shortcomings in mind, we consider that new technologies (and reactors) should have the following features: 
(a) The process should be carried out without catalysts due to difficulties and the cost of the their recovery.

(b) Low operating costs and investment costs are needed because the plastics, waste plastics, and products of degradation are inexpensive, and the conversion process must be profitable.

(c) Required frequency of cleaning of a reactor should be low.

(d) The industrial-scale plant should have modular construction to allow for greater flexibility of waste processing.

(e) The most profitable, seem to be such a technology, which will allow to use all obtained products for electricity production. In this case, the yield of liquid product, is not the essential process parameter. If the required product should to be a fuel-like mixture of hydrocarbons the yield of liquid product has to be high.

\section{Exergy Analysis - Methodological Remarks}

A number of environmental indicators can be defined that are related to the concept of sustainability. However, it seems that indicators based on thermodynamic considerations can better illustrate whether a development is sustainable. Environmental systems and industrial metabolisms obey the fundamental laws of thermodynamics. Whereas the first law of thermodynamics states that for every process, no energy can be destroyed or created, the second law notes that the quality of energy decreases. This quality, expressed as "useable energy," is called exergy. Exergy is the maximum amount of work that can be obtained from a material, taking into account the state of the surroundings [3, 4]. Therefore, exergy analysis is useful for assessing the genuine energetic efficiency of different industrial processes, including the conversion of waste to fuel or energy.

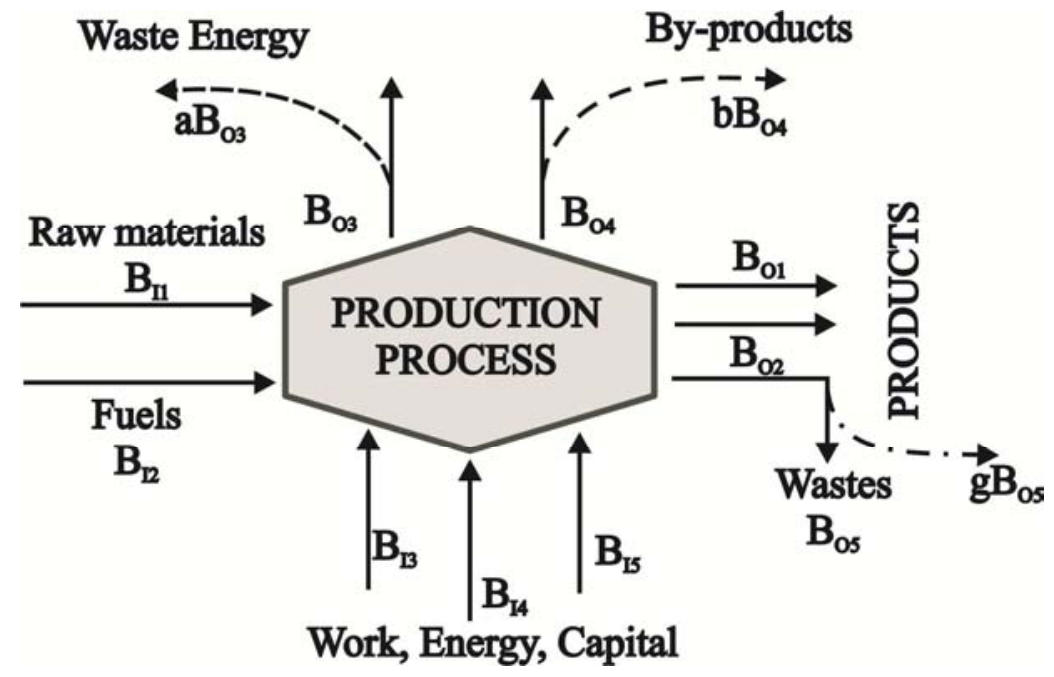

Figure 1. A general process diagram for exergy accounting (own elaboration, based on [5]).

The concept of exergy (as a general measure of work) is given by Z. Rant and H. D. Baehr, but the sources of the concept can be found in S. Carnot and J. H. Gibbs's earlier works.

A basic diagram of the exergy efficiency of a generic process is presented in Figure 1. The exergy efficiency $\eta_{B}$ of the process is expressed as follows:

$$
\eta_{B}=\frac{B_{O 1}+B_{O 2}+\alpha B_{O 3}+\beta B_{O 4}+\gamma B_{O 5}}{B_{I 1}+B_{I 2}+B_{I 3}+B_{I 4}+B_{I 5}+}
$$

where $B_{i}$ denotes the exergy of every input stream of materials, fuels, energy, capital, and labor (i.e., index $I j ; j$ $=1,2 . .5$ ) as well as the output streams for the products, waste products, produced energy, and waste energy (i.e., index $O J$ ). It is obvious that the higher the recycling ratio is (denoted by $\alpha, \beta$, and $\gamma$ ), the higher the exergy efficiency of the process will be.

Sciubba [5] proposed calculating the specific exergy $B i$ of the multicomponent $(I=1 . . N)$ mixture $j$ at a certain thermodynamic state (1) and a selected reference state $(0)$ as follows:

$$
\begin{gathered}
b_{j 1}=h_{j 1}-h_{j 0}-T_{0}\left(s_{j 1}-h s_{j 0}\right)+\sum_{i=1}^{N}\left(\mu_{j 1 i} c_{j 1 i}-\right. \\
\left.\mu_{j 0 i} c_{j 0 i}\right)
\end{gathered}
$$

where $h$ is the specific enthalpy $(\mathrm{J} / \mathrm{kg}), s$ denotes specific entropy $(\mathrm{J} / \mathrm{kg} / \mathrm{K}), T_{0}$ is the environmental temperature (for the reference state), $\mu$ is the specific chemical potential $(\mathrm{J} / \mathrm{kg})$, and $c$ is the mass concentration. Thus, the stream exergy can be expressed as follows:

$$
B_{j 1}=F_{j} \cdot b_{j 1}
$$

where $F_{j}$ is the mass stream of the multicomponent mixture $j$.

Exergy analysis is used for energetic and ecological assessments of different processes occurring in the environment [6-10] and at the industry level [11]. The basic principles of the methodology used to assess the impact of industrial processes on the environment and their energy efficiencies have been discussed in numerous scientific articles. Many scientists have analyzed the energy efficiency of thermal processes [12-15], energy production, fuel 
gasification and/or combustion [16-22] and biomass gasification [23-28]. Some studies have examined waste utilization methods and waste management systems based on comparative exergetic assessments [29-34] and the energetic/exergetic efficiency of selected processes [35, 36]. This paper presents a simplified assessment of the feedstock recycling process of waste polyolefins, in which the products of their thermal degradation are used for electricity generation.

\section{Feedstock Recycling of Polymers in Molten Metal}

There are also technologies that use molten metals or molten inorganic salts in the process of waste degradation. In the case of using in the process of molten metals, sometimes this method is called the Clementi Process [37]. The process is carried out usually at $600^{\circ} \mathrm{C}$. Such molten metals as tin, lead, and bismuth (or their alloys), 'in the liquid state, allow to create the reaction environment, what enables to stabilize the process.

Some years ago, a new type of vertical tubular reactor with a molten metal bed has been proposed (by the author of this paper) and useed in the laboratory-scale to convert waste polymers (plastics, rubber and etc.) into a valuable product, namely, a fuel-like mixture of hydrocarbons. The temperature of the process was decreased to $380^{\circ} \mathrm{C}-420^{\circ} \mathrm{C}$, and the surface of the molten metal is very small by comparison of the typical Clementi process (in ratio about 1:1000). The basic product is a mixture of hydrocarbons (i.e., paraffins and olefins C4-C24). The description of the laboratory setup as well as the results of the laboratory thermal degradation of waste polyethylene (PE) and polypropylene (PP) can be found in the previous papers [38, 39]. A very short summary of those experimental laboratory results (only for PE) is presented in Table 1.

Table 1. Product yields and the average composition of the liquid product obtained in the laboratory scale set up for the PE degradation in the tubular reactor with the molten metal bed.

\begin{tabular}{lll}
\hline Polymer & & PE \\
\hline Yield of the gas product & $\%$ mass & $5.8-7.3$ \\
Yield of the liquid product & $\%$ mass & $92.7-94.2$ \\
Yield of solid product & & 0 \\
C4-C10 ("light - gasoline fraction") & Mole\% & $48.8-52.8$ \\
C11-C16 ("heavy oil fraction") & Mole\% & $30.9-33.6$ \\
C17-C24 ("light waxes fraction") & Mole\% & $14.8-17.9$ \\
\hline
\end{tabular}

The experimental reaction rate of the degradation process was between $951 \mathrm{~kg} /(\mathrm{m} 3 \mathrm{~h})$ and $9183 \mathrm{~kg} /(\mathrm{m} 3 \mathrm{~h})$ depending on the process conditions. These experimental results were used to design pilot-scale plant and to create a mass balance of the process and next to calculate the exergy efficiency.

\section{Exergy Efficiency Calculations for the Described Technology with Electric Power Generation}

In the previous article [40], an exergy analysis was conducted in the case the process of thermal degradation of the blend of plastics that consisted of PE and PP. It was assumed That the final and the most required product was a (fuel-like) mixture of liquid hydrocarbons C4-C24, with the same composition which was obtained in laboratory experiments.

The scheme of the proposed pilot plant based on the vertical tubular reactor with molten metal was presented in the mentioned paper. It was assumed that the reaction rate was to be equal to $2877 \mathrm{~kg} /\left(\mathrm{m}^{3} \mathrm{~h}\right)$ - for the purposes of the exergy analysis. This assumption was made based on the results obtained in the case of a similar demonstration plant and is consistent with the results of laboratory experiments in relation to the assumed process conditions. It was assumed that biomass would be the main source of the energy required to heat the reactor. Based on the experience from the demonstration plant - it was assumed that $28 \mathrm{~kg} / \mathrm{h}$ of sawdust $(11.7 \mathrm{~kJ} / \mathrm{kg})$ ought to be gasified in the gasifier and combusted to heat the reactor. Combustion of the gaseous product (obtained by the thermal degradation of HDPE) was a supplementary source of energy. The temperature of flue heating gases was equal to $650^{\circ} \mathrm{C}$. Water was used to cool the $\mathrm{HC}$ product and for purification of flue gases in the scrubber. Electric power was needed for the feeders, fans, water and product pumps, control and acquisition data systems, and the lighting system. The exergy of required water streams and electric power were included in the analysis. The pilot reactor was $2 \mathrm{~m}$ high with an inner diameter of $0.2 \mathrm{~m}$. The mass of the molten metal (30\% tin and $70 \%$ lead by mass) was equal to about $320 \mathrm{~kg}$. The labor of six persons was needed to operate the plant. The results of the mass balance of the thermal degradation process of the HDPE $(50 \mathrm{~kg} / \mathrm{h})$ as well as the exergy efficiency of this process (equal to $79,5 \%$ ) were presented in the mentioned paper.

The aim of this study is to compare the previous analyzed installation (the main product - a mixture of liquid hydrocarbons) with another one in which the resulting product of the thermal degradation) is used only for electricity generation. In this last case, the only source of energy (for thermal degradation) is gasification of biomass and only HDPE is processed in the reactor. The scheme of the alternative plant - that is evaluated in this article - is presented in Figure 2. No cooling system is needed, and therefore smaller amounts of water and energy are required to perform the process. 


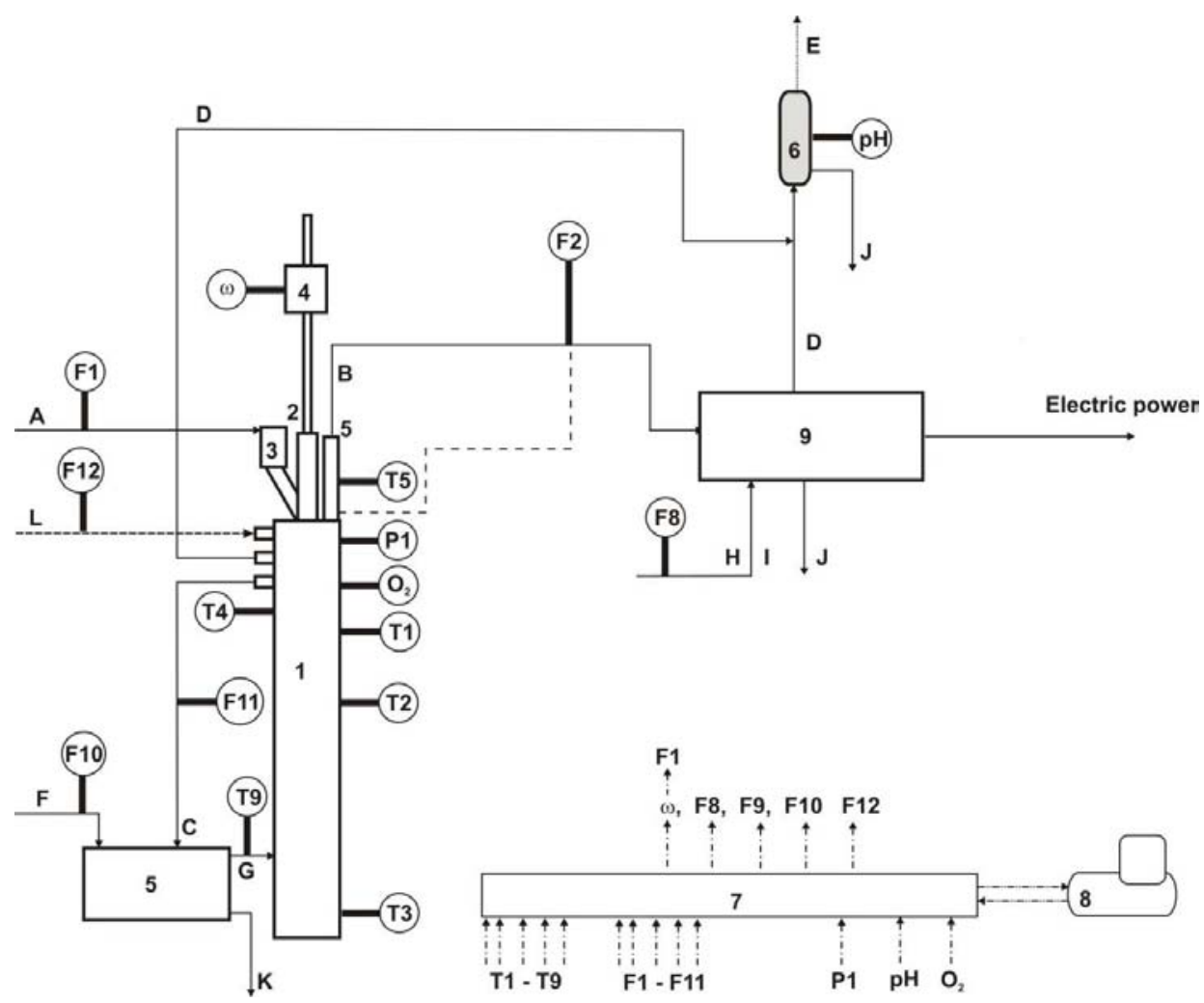

Figure 2. The scheme of the demonstration plant for thermal degradation of waste polyolefins in the vertical tubular reactor with molten metal with electric power generator; (1) the reactor with the heating jacket; (2) the inner tube of the reactor; (3) and (4) the feeder with the screw conveyor and the driver; (5) the gasifier of biomass (sawdust); (6) the scrubber for gas purification; (7) and (8) the control and data acquisition system; (9) electricity generator; $T_{i}, P_{i}, L_{i}$, $F_{i}, p H, O_{2}, \omega p$-sensors, detectors and transducers for temperature, pressure, liquid level, stream flow, $p H$, oxygen content, and speed of the screw conveyor The streams are labeled: $A$ - waste plastics, $B$ - vapors of total product (mixture of gaseous hydrocarbons), $C$ - the solid product (to gasifier), $D$ - gas to scrubber, $E$ - gas emission, $F$ - biomass (sawdust), $G$ - heating gases from gasifier to heating mantle, $I$-water supply, $J$-wastewater, $K$-ash, $L-$ nitrogen.

Assessment and calculation of the exergy efficiency of the process were based on the following assumptions:

(1) No mechanical disintegration of the waste was performed, as no additional energy was needed.

(2) Generally, the total exergy of the stream is the sum of kinetic exergy, potential exergy, nuclear exergy, physical (or thermomechanical) exergy, and chemical exergy. However, only chemical and physical exergy are taken into consideration efficiency calculations in this study.

(3) The reference state was $\mathrm{T}=298.15 \mathrm{~K}$ and $\mathrm{P}=0.101$ $325 \mathrm{MPa}$.

(4) The calculations of physical exergy were based on standard values of enthalpy and entropy.

(5) The exergy of the sawdust was calculated using the higher heating value of the sawdust. The exergy of the waste was based on the higher heating value of HDPE.

(6) Mineral impurities consisted of $\mathrm{SiO}_{2}$.

(7) The exergy of the coke was calculated based on the higher heating values for coal, carbon black, and tar. It was assumed that the coke contained a 1:1:1 mixture of these components.

(8) The exergy of electricity was equal to energy power.

(9) The exergy of waste heat was calculated based on Equation (4).

$$
B_{i}=\left(1-T_{0} / T\right) \cdot Q_{i}
$$

(10)The exergy of $\mathrm{SO}_{2}, \mathrm{NO}_{\mathrm{x}}$, construction materials, labor, and capital was not considered.

(11)A continuous process is analyzed in the study..

(12)The values of the chemical exergy of the system components are presented in Table 2.

(13)As electrical energy (active power) can be fully converted into work, the exergy content of electricity is equivalent to the energy content of the electrical flow. It can be considered a particular case of the exergy of a work stream [41]. In other words, the exergy associated with electricity is equal to the energy [42]. The generated electric power $(P)$ has been calculated using Equation (5) [4]:

$$
P=F_{\text {mol.CO2 }} R T_{0} \ln \left(\frac{p_{\text {CO2.out }}}{p_{\text {CO2 }, \text { atm }}}\right)
$$

where, $F_{m o l, C O 2}$ is the molar stream of carbon dioxide $(\mathrm{kmol} / \mathrm{h}) ; R$ is the gas constant $(\mathrm{kJ} / \mathrm{kmol} / \mathrm{K}) ; T_{0}$ is the temperature of the environment $(298 \mathrm{~K})$; and $p_{\mathrm{CO} 2 \text {,out }}$ and $p_{C O 2, \text { atm }}$ are the partial pressures of carbon dioxide in flue gases and in the environment, respectively. It was assumed that the partial concentration of $\mathrm{CO}_{2}$ in the environment was equal to $385 \mathrm{ppm}_{(\mathrm{Vol})}$. Ideal conditions for combustion were assumed. All gases were considered ideal. 
(1) There was complete combustion and no exergy loss, with the exception of the cooling water.

(2) The total waste degradation products flowing from the reactor without condensation are used to produce electricity in the electric power generator. No cooling system is needed.

(3) The amount of sawdust has to be increased from 28 $\mathrm{kg} / \mathrm{h}$ (that was required in a similar plant converting wastes to liquid product) to $34 \mathrm{~kg} / \mathrm{h}$. The stream of flue gases also increased to $1129.8 \mathrm{~kg} / \mathrm{h}$.

(4) The reaction rate was assumed to be $2877 \mathrm{~kg} /\left(\mathrm{m}^{3} \mathrm{~h}\right)$. The pilot reactor was $2 \mathrm{~m}$ high with an inner diameter of $0.2 \mathrm{~m}$. The mass of the molten metal $(30 \%$ tin and $70 \%$ lead by mass) was about $320 \mathrm{~kg}$. The labor of six persons (as the plant consisted of four reactors) was needed to operate the process in the plant - similarly as in the previous study.

Table 2. Chemical exergy of the considered components.

\begin{tabular}{|c|c|c|c|c|}
\hline & Substance & & Unit of measure & Value of the exergy $b_{\text {chi }}$ \\
\hline 1 & Polyethylene & $\mathrm{PE}_{(\mathrm{S})}$ & & $48,360.00$ \\
\hline 2 & Silica & $\mathrm{SiO}_{2(\mathrm{~S})}$ & & 36.61 \\
\hline 3 & Coke & Tar, carbon black $(\mathrm{s})$ & & $39,639.72$ \\
\hline 5 & Light "gasoline" fraction of the liquid product & $\left(\mathrm{C}_{4}-\mathrm{C}_{10}\right)_{(\mathrm{L})}$ & & $48,147.01$ \\
\hline 6 & Heavy "oil" fraction of the liquid product & $\left(\mathrm{C}_{11}-\mathrm{C}_{16}\right)_{(\mathrm{L})}$ & & $48,201.46$ \\
\hline 7 & "Light waxes" of the liquid product & $\left(\mathrm{C}_{17}-\mathrm{C}_{24}\right)_{(\mathrm{L})}$ & $1-t_{1}$ & $47,686.29$ \\
\hline 9 & Water (vapor) & $\mathrm{H}_{2} \mathrm{O}_{(\mathrm{G})}$ & & 527.34 \\
\hline 10 & Carbon dioxide & $\mathrm{CO}_{2(\mathrm{G})}$ & & 442.63 \\
\hline 11 & Nitrogen & $\mathrm{N}_{2(\mathrm{G})}$ & & 25.70 \\
\hline 12 & Oxygen & $\mathrm{O}_{2(\mathrm{~g})}$ & & 24.63 \\
\hline 13 & Sulfur dioxide & $\mathrm{SO}_{2(\mathrm{G})}$ & & $4,892.07$ \\
\hline 14 & Nitrogen dioxide & $\mathrm{NO}_{2(\mathrm{G})}$ & & $1,208.55$ \\
\hline
\end{tabular}

The idea of the mass balance, performed for the plant is presented in Figure 3. The detailed mass balances of the process of gasification of sawdust and the process of combustion of hydrocarbons (obtained by degradation) are presented in Table 3 and in Table 4 . Water is used by the scrubber and for cooling of the electric power generator.
Electric power is also needed for feeders (of wastes and sawdust), fans, control and data acquisition systems, and lighting systems. The required water streams and electric power are presented in Table 5 and the overall mass balance of the plant in Table 6 .

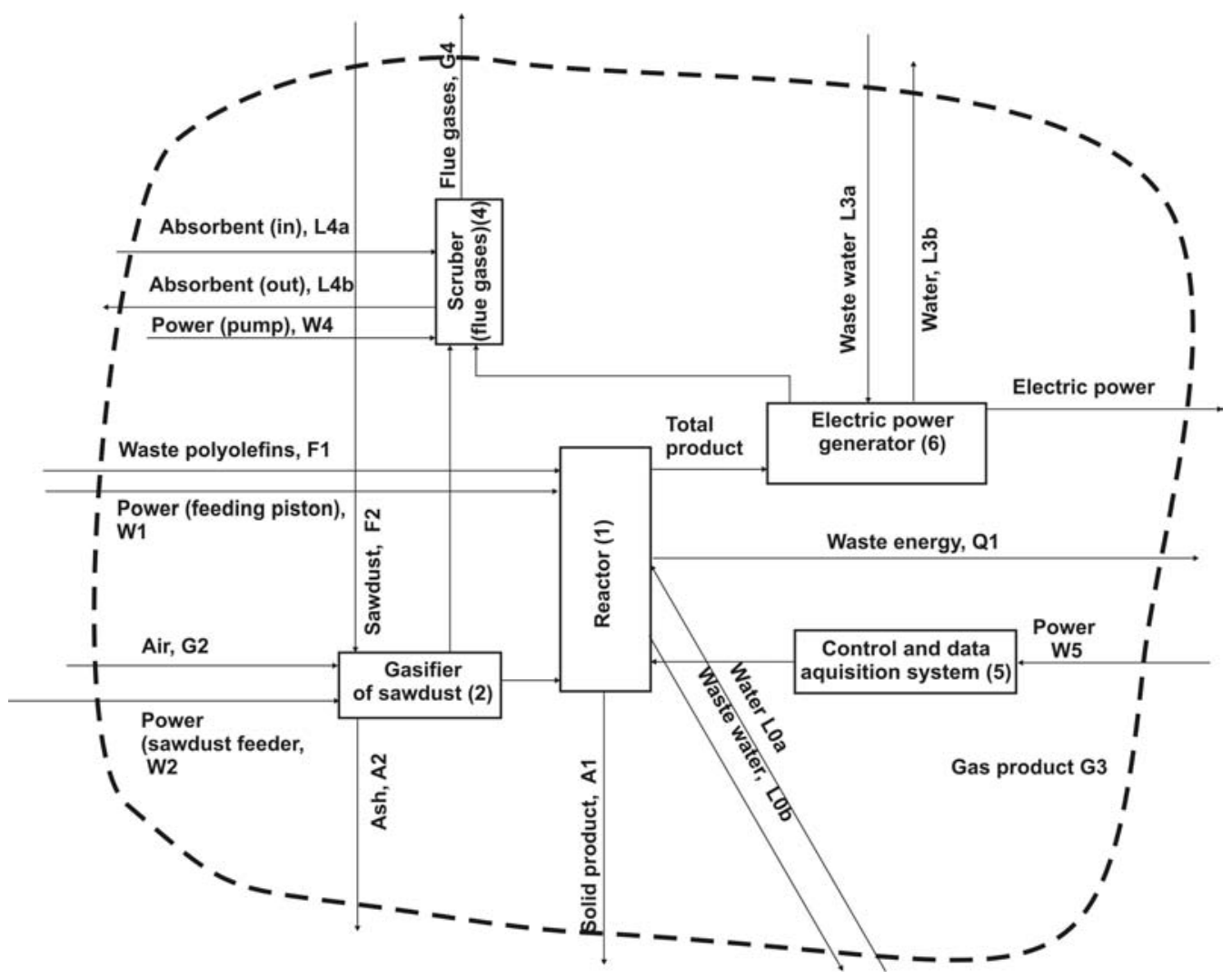

Figure 3. The scheme of the total mass balance for the single module (reactor) of the demonstration plant with electric power generator. 
Table 3. The mass balance of the gasification and combustion of the biomass in the plant with electricity generation.

\begin{tabular}{|c|c|c|}
\hline & Stream & Composition \\
\hline & $\mathrm{kg} / \mathrm{h}$ & $\%$ mass \\
\hline \multicolumn{3}{|l|}{ Stream of the total biomass: } \\
\hline Total sawdust, & 34.00 & \\
\hline Sawdust (dry mass) & 28.56 & 84.00 \\
\hline Water & 5.44 & 16.00 \\
\hline \multicolumn{3}{|c|}{ Composition of the dry sawdust } \\
\hline Ash & & 0.80 \\
\hline Hydrogen & & 6.60 \\
\hline Nitrogen & & 0.01 \\
\hline Sulfur & & 0.01 \\
\hline Carbon & & 51.00 \\
\hline Air (for combustion): & 254.64 & \\
\hline Oxygen & 58.79 & 23.0 \\
\hline Nitrogen and other inerts & 195.85 & 77.0 \\
\hline Water (vapor) & 18.45 & 7.76 \\
\hline Nitrogen & 161.29 & 67.90 \\
\hline Oxygen & 13.78 & 5.81 \\
\hline Sulfur dioxide & 0.0047 & 0.00198 \\
\hline Nitrogen oxides & 0.0077 & 0.00325 \\
\hline Dust & 0.0094 & 0.00396 \\
\hline Solid product - ash & 0.217 & \\
\hline
\end{tabular}

Table 4. The mass balance of total product combustion in the plant with electric power generator.

\begin{tabular}{lll}
\hline & Stream & Composition \\
\cline { 2 - 3 } & $\mathbf{k g} / \mathbf{h}$ & \% mass \\
\hline Air for combustion process: & 792.70 & 23.0 \\
Oxygen & 183.00 & 77.0 \\
Nitrogen and other inerts & 609.70 & \\
Flue gases: & 840.71 & 17.68 \\
Carbon dioxide & 148.65 & 8.00 \\
Water (vapor) & 67.25 & 72.52 \\
Nitrogen & 609.70 & 1.80 \\
Oxygen & 15.11 & 0.00 \\
Sulfur dioxide & 0.00 & 0.00 \\
Nitrogen oxides & 0.00 & 0.00 \\
Dust & 0.00 & \\
\hline
\end{tabular}

Table 5. The mass balance of water and electric power.

\begin{tabular}{lll}
\hline & Electric power & Water \\
\cline { 2 - 3 } & $\mathbf{k W}$ & $\mathbf{k g} / \mathbf{h}$ \\
\hline The reactor & 12.0 & \\
The feeder, the screw conveyor, and the driver & 2.0 & \\
Control and acquisition data system & & \\
The gasifier: & 1.5 & \\
The feeder & 0.2 & \\
Air fan & 16.0 & \\
Total electric power & & \\
The electricity generator & & \\
Cooling water & & \\
Scrubber & & \\
(Scrubber capacity $0.95 \mathrm{~m}^{3}$ & & 5.64 \\
Making up $0.9 \mathrm{~m}^{3} /$ week $)$ & & 12.49 \\
Water & & 19.60 \\
Running (drinking) water $\left(0.3 \mathrm{~m}^{3} /\right.$ day) & & 20.09 \\
Water & & 19.60 \\
Total water & & 0.49 \\
Wastewater & & \\
Process water & & \\
Water phase from the degradation process & & \\
\hline
\end{tabular}


Table 6. The overall mass balance of the process with electric power generator.

\begin{tabular}{llll}
\hline Input streams & & Output streams & $\mathrm{kg} / \mathrm{h}$ \\
\hline & $\mathrm{kg} / \mathrm{h}$ & & 0 \\
Waste stream: & 50 & Liquid product: & 0 \\
PE & 48.4 & Hydrocarbons (organic phase) & 0 \\
Impurities & 0.9 & Water phase & $1,129.8$ \\
Water & 0.7 & & 202 \\
Air: & $1,047.3$ & Flue gases: & 90.4 \\
Oxygen & 240.9 & Carbon dioxide & 31.8 \\
Nitrogen & 806.5 & Water & 805.6 \\
& & Nitrogen & 1.5 \\
Fuel & 34.0 & Oxygen & 1.3 \\
Dry sawdust & 26.6 & Solid product: & 0.2 \\
Water & 5.4 & Coke from waste degradation & 19.6 \\
Water & 19.6 & Ash (from sawdust gasification) & $1,150.9$ \\
Total & $1,150.9$ & Wastewater & \\
\hline
\end{tabular}

The generated electric power $\mathrm{P}$ was equal to $906.5 \mathrm{~kW}$ (with a power generation efficiency $=70 \%$ ) and the stream of exergy $\left(B_{O 3}\right)$ was equal to $=2284 \mathrm{MJ} / \mathrm{h}$. The exergetic efficiency of the plant described in this case to be equal to $81.9 \%$ - in comparison to $79,5 \%$ (calculated for the previous installation). The exergy efficiency of the process is high, which means that thermal cracking is a more valuable and ecological technology than the incineration of waste plastics. However, the setup with an electric power generator may be the best solution for utilization of this type of waste because of cutting down the costs and energy required for transport and further processing of the liquid mixture of hydrocarbons in the refinery. The exergetic efficiency of the presented process, carried out in the described plant, is over $81 \%$ in the case of electricity generation and about $79 \%$ in the case of fuel production.

The exergetic efficiencies calculated seem to be too high too, but similar values to them have been calculated by other authors for various other processes, as, for example, for recycled exhaust gases and fuel cell technology $(\sim 78 \%$; [43]), the solid-oxide fuel cell (SOFC) systems ( $75 \%$; [44]), combustion of methanol with utilization of solar energy or waste heat $(\sim 75-78 \%$; [17] and combustion systems using flameless mode (70-90\%; [45].

If exergy of construction materials, labor, and capital is included in the calculations, the true efficiency of the total process will not be as high-even if the waste heat generated in the process is recovered. However, the efficiency ought to be essentially higher than the efficiency of the incineration process of waste plastics, which usually amounts to $25-35 \%$. It seems that a setup with electric power generator has more advantages due to higher efficiency, elimination of the environmental costs of transport of the products to refineries, and the higher usefulness of electricity than obtained gaseous and liquid products (hydrocarbons). The profiles of all streams and their exergy values for the considered case are shown in Table 7.

Table 7. The profile of the all balance streams with electric power generation.

\begin{tabular}{|c|c|c|c|c|c|c|c|c|c|c|c|c|c|}
\hline & & 1 & 2 & 3 & 4 & 5 & 6 & 7 & 8 & 9 & 10 & 11 & 12 \\
\hline Stream symbol & & F1 & $\mathrm{F} 2$ & G2 & $\Sigma \mathrm{La}$ & W3 & A1 & A2 & A3 & G4 & $\Sigma \mathrm{Lb}$ & $\Sigma \mathrm{W}$ & $\Sigma \mathrm{Q} 1$ \\
\hline Exergy balance & & BI1 & BI2 & BI3 & BI4 & BO1 & $\mathrm{BO} 2$ & $\mathrm{BO} 3$ & BO4 & BO5 & BO6 & BI5 & BO7 \\
\hline Temperature & $\mathrm{K}$ & 283 & 283 & 283 & 283 & 298 & 673 & 673 & 298 & 423 & 293 & - & - \\
\hline Pressure & $\mathrm{MPa}$ & 0.1 & 0.1 & 0.1 & 0.3 & 0.1 & 0.1 & 0.1 & 0.1 & 0.1 & - & - & - \\
\hline $\begin{array}{l}\text { Mass flow } \\
\text { Composition }\end{array}$ & $\mathrm{kg} / \mathrm{h}$ & 50 & 34 & 1047 & 19.6 & 45.1 & 1.29 & 0.20 & - & 1130 & 19.6 & & \\
\hline $\mathrm{PE}$ & & 96.8 & & & & & & & & & & & \\
\hline $\mathrm{H}_{2} \mathrm{O}(\mathrm{L})$ & & 1.4 & 16.0 & & 100 & & & & & & $\sim 100$ & & \\
\hline $\mathrm{C}_{4}-\mathrm{C}_{10}(\mathrm{~L})$ & & & & & & 41.7 & & & & & & & \\
\hline $\mathrm{C}_{11}-\mathrm{C}_{16}(\mathrm{~L})$ & & & & & & 33.0 & & & & & & & \\
\hline $\mathrm{C}_{17}-\mathrm{C}_{24}(\mathrm{~L})$ & & & & & & 25.3 & & & & & & & \\
\hline $\mathrm{CO}_{2}(\mathrm{G})$ & $\%$ & & & & & & & & & 17.9 & & & \\
\hline $\mathrm{H}_{2} \mathrm{O}(\mathrm{G})$ & & & & & & & & & & 8.0 & & & \\
\hline $\mathrm{N}_{2}(\mathrm{G})$ & & & & 77.0 & & & & & & 71.3 & & & \\
\hline $\mathrm{O}_{2}(\mathrm{G})$ & & & & 23.0 & & & & & & 2.8 & & & \\
\hline $\mathrm{SiO}_{2}$ & & 1.8 & & & & & 70 & 100 & & & & & \\
\hline Coke & & & & & & & 30 & & & & & & \\
\hline Sawdust & & & 84.0 & & & & & & & & & & \\
\hline Exergy stream & $\mathrm{MJ} / \mathrm{h}$ & 2340.7 & 363.1 & 26.7 & 0.98 & 2284.4 & 15.4 & 0.01 & 0.04 & 190.6 & 0.98 & 57.6 & 293.4 \\
\hline
\end{tabular}

Construction of a device (a motor or a turbine) for the combustion of the gaseous mixture of hydrocarbons $(\mathrm{CH} 4$ to $\mathrm{C} 24 \mathrm{H} 50$ ) is not the subject of this paper. In the opinion of the author, construction of a proper engine for this purpose is possible. Some publications (with an engineering profile) and information from technical literature also show that it is 
possible. Among them, Jones et al. [46] and Rahm et al. [47] have pointed to such possibilities in their publications. They demonstrated that different technical solutions are possible, although no specific engine or another thermal machine is indicated (in these publications). Examples of technical solutions of engines that use fuels (of a wide range of hydrocarbons) are diesel engines with a dual power-supply system for compression ignition: Many companies have carried out studies on the possibility of introducing or mixing LPG (Liquefied Petroleum Gas) and/or LNG/CNG (Liquefied Natural Gas/Compressed Natural Gas) with the diesel fuel. The system Dual Fuel Diesel (DFD) simultaneous supply of the diesel motor by two different fuels, diesel and LPG-had already been used by Rudolf Diesel in order to the optimization of his engine. Such a solution could even gain some advantages, such as an increase in driving dynamics (increase in power and torque), reducing the pressure in the fuel system components, and decreasing the emission of pollutants into the atmosphere. Currently, the modern system of DFD can be applied to all diesel engines, both with turbo and without turbo, as well as with the electronically controlled throttle and is really used in the latest designs of diesel engines, including turbocharged. For example, some installations of Electronic Fuel Control (EFC) can dose fuel with the ratio 85:15 (85\% LNG, 15\% diesel). Some modern diesel engines are capable of running using crude oil and LNG. They are used in the oil and gas exploration and production industries. MAN Diesel \& Turbo develops and manufactures dual-fuel engines that run on both gas and diesel fuel, which are based on diesel engines. So, these cited examples point to the feasibility of construction of a combustion engine that allows the use of a mixture of hydrocarbons $(\mathrm{C} 1-\mathrm{C} 24)$ in practice.

\section{Conclusions}

The known technologies for utilizing waste plastics, particularly incineration, introduce high entropy streams into the environment and require a great deal of attention. At present, there are a great variety of options to use and recycle waste. Depending on local conditions, specific situations require the selection of the best technology that takes into account several implications: ecological, social, economic, legal, and technical consequences. The key to the decision should be the energy or exergy efficiency of the considered methods or processes. Therefore, it seems that the best way to assess and compare different technologies (or even waste management systems) for waste utilization is performing a thermodynamic analysis, as most of these implications may be taken into account in the evaluation process of the processes considered. The application of exergy analysis to account for the amount of raw materials as well as the wastes and waste energy used for energy production is effective in screening alternative technologies for realizing sustainable development. This also allows for indicating the best ways for direct or indirect waste recycling that may be defined for a single industrial process as well as for a waste management system at the national or international levels to be identified.

The method of the thermal decomposition of waste PE or PP in a molten metal bed is a promising process in comparison with catalytic cracking in the vessel or tubular flow reactors. In the proposed method, catalysts and stirring are not needed. Over $90 \%$ of scrap polyolefins may be converted into a liquid product. This liquid product may be used for producing fuel or other chemical production.

Assuming that the real efficiency may be not so high (as was calculated) because some input exergy streams (of labor, capital, and construction materials) were neglected in the calculations performed, it should yet be essentially higher than the efficiency of the incineration processes of wastes (which usually does not exceed 30-40\%). This means that the thermal degradation process of waste plastics, particularly using electric power generation, could be considered environmentally friendly.

It is obvious that the obtained liquid mixture has to be processed in further processes - to fuels or to electricity. However, the exergetic efficiencies calculated for the proposed installations (with electricity generation or without it) are very similar. The choice of one of the possible solutions will depend primarily on the demand for the type of energy (fuel or electricity), the possibility of connecting to the power grid and the distance of the processing plant to the refinery, where the mixture of the hydrocarbons could be reprocessed to gasoline or diesel. This means that the thermal degradation process of waste plastics using the tubular reactor with the molten metal bed and with the electric power generation should be considered profitable and environmentally friendly if on the one side the long distance to the refinery causes the increase of the costs and on the other side there is a possibility of connecting the electric power generator to the grid and the price of energy is profitable for the owner of the processing plant

\section{References}

[1] AGUADO J., SERRANO D. P. ESCOLA M. J. Fuels from Waste Plastics by Thermal and Catalytic Processes: A Review. Ind. Eng. Chem. Res. 47 (21), 7982, 2008.

[2] SCHEIRS J., KAMINSKI W., (editors), Feedstock Recycling and Pyrolysis of Waste Plastics: Converting Waste Plastics into Diesel and Other Fuels. Wiley Series in Polymer Sciences, John Wiley \& Sons, Ltd. 2006.

[3] DEWULF J. P., LANGENHOV VAN H. Quantitative Assessment of Solid Waste Treatment Systems in the Industrial Ecology Perspective by Exergy Analysis. Env. Sci. Technol. 36, 1130, 2002.

[4] WALL G., GONG M. On exergy and sustainable development Part 1: Conditions and concepts. Exergy, an International Journal 1 (3), 128, 2001; Part 2 Indicators and Methods. Exergy, an International Journal 1 (4): 217, 2001.

[5] SCIUBBA E. Extended exergy accounting applied to energy recovery from waste: The concept of total recycling Energy 28, 1315, 2003. 
[6] PETELA R. An approach to the exergy analysis of photosynthesis. Solar Energy 82, 311, 2008.

[7] ROSEN M. Exergy conservation: An alternative to conserving the already conserved quantity energy Exergy, an International Journal 2, 59, 2002.

[8] CONNELLY L., KOSHLAND C. P. Exergy and industrial ecology-Part 1: An exergy-based definition of consumption and a thermodynamic interpretation of ecosystem evolution. Exergy, An International Journal 1 (3), 146, 2001; Part 2. A non-dimensional analysis of means to reduce resource depletion, Exergy, an International Journal 1 (4), 234, 2001.

[9] MEESTER DE B., DEWULF J., JANSSENS A., VAN LANGENHOVE $\mathrm{H}$. An Improved Calculation of the Exergy of Natural Resources for Exergetic Life Cycle Assessment (ELCA). Environ. Sci. Technol 40, 6844, 2006.

[10] JØRGENSEN S. E, NIELSEN S. N. Application of exergy as thermodynamic indicator in ecology. Energy 32, 673, 2007.

[11] SZARGUT J Exergy analysis: technical and ecological applications. WIT-press. Southampton, Boston. 2005.

[12] KOTAS T. J., The Exergy Method of Thermal Plant Analysis, Krieger Publishing Company, Malabar, Florida, 1996, ISBN 089464-946-9.

[13] SZARGUT J. Sequence method of determination of partial losses in thermal systems. Exergy, an International Journal 1 (2), 85, 2001.

[14] ALJUNDI I. H . Energy and exergy analysis of a steam power plant in Jordan. Applied Thermal Engineering 29 (2-3), 324, 2009.

[15] REDDY V. S., • KAUSHIK S. C., TYAGI S. K. Exergetic analysis and evaluation of coal-fired supercritical thermal power plant and natural gas-fired combined cycle power plant. Clean Techn Environ Policy 16, 489, 2014.

[16] SENGUPTA S., DATTA A., DUTTAGUPTA S. Exergy analysis of a coal-based $210 \mathrm{MW}$ thermal power plant. Int J. Energy Res. $31,14,2007$

[17] NUWAN H. P., DE ALWIS S., MOHAMAD A. A., MEHROTRA A. K. Exergy Analysis of Direct and Indirect Combustion of Methanol by Utilizing Solar Energy or Waste Heat. Energy \& Fuel 23 (3), 1723, 2009.

[18] SOMM S. K., DATTA A. Thermodynamic irreversibilities and exergy balance in combustion processes. Progress in Energy and Combustion Science 34, 251, 2008.

[19] BLEEKER M., GORTER S., KERSTEN S., VAN DER HAM L., VAN DEN BERG H., VERINGA H., Hydrogen production from pyrolysis oil using the steam-iron process: a process design study. Clean Techn Environ Policy 12, 125, 2010.

[20] KLEMEŠ J. J., VARBANOV P. S. Efficient and clean production of fuels and biofuels: a summary. Clean Techn Environ Policy 14, $371,2012$.

[21] BRAU J. F., MORANDIN M., BERNTSSON T., Hydrogen for oil refining via biomass indirect steam gasification: energy and environmental targets. Clean Techn Environ Policy 15, 501, 2013.

[22] SHARIATI M. H. AND FARHADI F. Exergy Analysis of Waste Heat Recovery Section in Steam-Natural, Gas Reforming Process. Energy Fuels 29, 3322, 2015.
[23] TOONSSEN R., WOUDSTRA N., VERKOOIJEN A. H. M. Exergy analysis of hydrogen production plants based on biomass gasification. International Journal of Hydrogen Energy 33, 4074, 2008.

[24] JURAŠČIK M., SUES A., PTASINSKI K. J., Exergy analysis of synthetic natural gas production method from biomass, Energy 35 $880,2010$.

[25] ZHANG X., SOLLI C., HERTWICH E. G., TIAN X., ZHANG S. Exergy Analysis of the Process for Dimethyl Ether Production through Biomass Steam Gasification. Ind. Eng. Chem. Res. 48, 10976, 2009.

[26] MÍNGUEZ M., JIMÉNEZ Á., RODRÍGUEZ J., GONZÁLEZ C., LÓPEZ I., NIETO R. Analysis of energetic and exergetic efficiency, and environmental benefits of biomass integrated gasification combined cycle technology. Waste Manag Res 4, 401, 2013.

[27] XYDIS G., NANAKI E., KORONEOS C. Exergy analysis of biogas production from a municipal solid waste landfill, Sustainable Energy Technologies and Assessments 4, 20, 2013.

[28] KEEDY J., PRYMAK E., MACKEN N., POURHASHEM G., SPATARI S., MULLEN CH. A., BOATENG A. A., Exergy Based Assessment of the Production and Conversion of Switchgrass, Equine Waste, and Forest Residue to Bio-Oil Using Fast Pyrolysis. Ind. Eng. Chem. Res. 54, 529, 2015.

[29] MEWS D., TOKARZ A. Concept of waste recovery, In "Strategies of waste energy use", by Fratzscher W., 2000.

[30] FRATZSCHER W., STEPHAN K. Waste Exergy utilisation - An appeal for an entropy based strategy. Int. J. Therm. Sci. 40, 311, 2001.

[31] FRATZSCHER W., STEPHAN K. Waste energy usage and entropy economy, Energy 28, 1281, 2003.

[32] SUTER P. A new guiding paradigm for waste disposal. Energy 28,1335, 2003.

[33] LUORANEN M., SOUKKA R., DENAFAS G., HORTTANAINEN M. Comparison of energy and material recovery of household waste management from the environmental point of view - Case Kaunas, Lithuania. Applied Thermal Engineering 29, 938, 2010.

[34] RENÓ GRILLO M. L., TORRES F. M., DA SILVA R. J., SANTOS SOARES J. J. C. , Motta Melo M. N. Exergy analyses in cement production applying waste fuel and mineralizer. Energy Conversion and Management 75, 98, 2013.

[35] GUO S., XIAO Y., TIAN W., ZHANG Z., Energy and Exergy Analysis of a Novel efficient Combined Process by Hydrothermal, Degradation and Superheated Steam Drying of Degradable Organic Wastes. J. of Thermal Science 15 (3), 274, 2006.

[36] TARIGHALESLAMI A. H., OMIDKHAH M. R., GHANNADZADEH A., HESAS R. H. Thermodynamic evaluation of distillation columns using exergy loss profiles: a case study on the crude oil atmospheric distillation column, Clean Techn Environ Policy, 14, 381, 2012.

[37] NEWBOROUGH M., HIGHGATE P., VAUGHAN P. Thermal depolymerisation of scrap polymers. Applied Thermal Engineering 22 (17), 1875, 2002. 
[38] STELMACHOWSKI M. Conversion of waste rubber to the mixture of hydrocarbons in the reactor with molten metal. Energy Conversion and Management 50, 1739, 2009.

[39] STELMACHOWSKI M. Thermal conversion of waste polyolefins to the mixture of hydrocarbons in the reactor with molten metal bed. Energy Conversion and Management 51, 2016,2010

[40] STELMACHOWSKI M. Feedstock recycling of waste polymers by thermal cracking in molten metal: thermodynamic analysis. Journal of Material Cycles and Waste Management 16, 211, 2014.

[41] QUEROL E., GONZALEZ-REGUUERAL B., PEREZBENDITO J. Practical Approach to Exergy and Thermoeconomic Analyses of Industrial Processes, Chapter 2. Page 26, Series: SpringerBriefs in Energy, Springer. 2013.

[42] DINCER I., ROSEN M. A. Exergy. Energy, Environment and Sustainable Development, Chapter 2, page 25. Second Edition, Elsevier, 2013.
[43] HARVEY S. P., RICHTER H. J. (1994) Gas Turbine Cycles With Solid Oxide Fuel Cells-Part I: Improved Gas Turbine Power Plant Efficiency by Use of Recycled Exhaust Gases and Fuel Cell Technology, J. Energy Resour. Technol. 116(4):305-311.

[44] BEDRINGÅS K. W., ERTESVÅG I. S., BYGGSTØYL S., MAGNUSSEN B. F., (1997) Exergy analysis of solid-oxide fuel-cell (SOFC) systems. Energy 22 (4), 305, 1997.

[45] HOSSEINI S. E., WAHID M. A. Enhancement of exergy efficiency in combustion systems using flameless mode, Energy Conversion and Management 86, 1154, 2014.

[46] JONES R., GOLDMEER J. MONETTI B. Addressing Gas Turbine. Fuel Flexibility, GER4601(06/09), site.geenergy.com. 2011.

[47] RAHM S., GOLDMEER J., MOLIERE M., ERANKI A. Addressing Gas Turbine. Fuel Flexibility, GER4601(06/09), site.ge-energy.com, paper was originally presented at the POWER-GEN Middle East conference in Manama, Bahrain on February 17-19, 2009. 